\title{
Neem Oil Used as a "Complex Mixture" to Improve In Vitro Shoot Proliferation in Olive
}

\author{
Maurizio Micheli ${ }^{1,2}$ \\ Dipartimento di Scienze Agrarie, Alimentari e Ambientali, Università degli \\ Studi di Perugia, Borgo XX Giugno 74, Perugia 06121, Italy \\ Daniel Fernandes da Silva ${ }^{1}$ \\ Departamento de Biologia, Universidade Federal de Lavras, Caixa Postal \\ 3037, Lavras 37200-000, Brazil
}

\begin{abstract}
Daniela Farinelli and Graziana Agate
Dipartimento di Scienze Agrarie, Alimentari e Ambientali, Università degli Studi di Perugia, Borgo XX Giugno 74, 06121 Perugia, Italy
\end{abstract}

Rafael Pio

Departamento de Agricultura, Universidade Federal de Lavras, Caixa Postal 3037, 37200-000 Lavras, Minas Gerais, Brazil

\section{Franco Famiani \\ Dipartimento di Scienze Agrarie, Alimentari e Ambientali, Università degli Studi di Perugia, Borgo XX Giugno 74, 06121 Perugia, Italy}

Additional index words. adventitious shoots, apical dominance, Azadirachta indica A. Juss, micropropagation, Olea europaea, secondary sprouts

\begin{abstract}
Shoots of the olive cultivar Moraiolo were previously cultured in aseptic conditions on Olive Medium (OM), with the addition of $4 \mathrm{mg} \cdot \mathrm{L}^{-1}$ of zeatin, $30 \mathrm{~g} \cdot \mathrm{L}^{-1}$ of sucrose, and $7 \mathrm{~g} \cdot \mathrm{L}^{-1}$ of agar. Then, 1-cm long uninodal explants with two leaves and two axillary buds were excised from the proliferated masses and placed on the same proliferation medium enriched with four concentrations of neem oil $(0$-control, 0.1 , 0.5 , and $1.0 \mathrm{~mL} \cdot \mathrm{L}^{-1}$ ), added before sterilization. The addition of $0.1 \mathrm{~mL} \cdot \mathrm{L}^{-1}$ of neem oil to the medium gave an improvement in shoot regeneration. More vigorous shoots (longer proliferated shoots) were obtained along with a higher number of nodes (multiplication rate). Overall, there was a significant increase in the total fresh and dry proliferated weights. To our knowledge, this is the first report showing a strong and beneficial effect of neem oil, used as a "complex mixture," on in vitro plant regeneration.
\end{abstract}

Micropropagation is used worldwide because of a number of advantages with respect to conventional propagation systems. Among the advantages are the high genetic and sanitary quality of the propagated material and the potential for the production of a large number of plants in a small space and in a short period of time (Kavand et al., 2011). Currently, micropropagation is used for the multiplication of rootstocks and cultivars in a number of fruit species, such as pear, kiwi,

\footnotetext{
Received for publication 20 Nov. 2017. Accepted for publication 6 Feb. 2018

The research was funded by the "Dipartimento di Scienze Agrarie, Alimentari e Ambientali - Università degli Studi di Perugia," Italy. Daniel Fernandes da Silva contributed to this article as a recipient of the fellowship "Bolsista CAPES PDSE 99999.006582/ 2015-00.”

${ }^{1}$ Joint first authors

${ }^{2}$ Corresponding author. E-mail: maurizio.micheli@ unipg.it.

This is an open access article distributed under the CC BY-NC-ND license (http://creativecommons. org/licenses/by-nc-nd/4.0/).
}

banana, pineapple, and others (Balla and Mansvelt, 2013; Dobránszki and Silva, 2010). However, many woody and fruit tree species are still difficult to propagate using in vitro culture and others still have particular problems (Jain and Haggman, 2007). Olive (Olea europaea L.) is usually propagated through conventional asexual methods, such as by cutting or grafting. However, these techniques have some limitations because they are too slow and/or are inefficient for some cultivars with a high commercial value (Rkhis et al., 2011). With the aim of overcoming these difficulties, micropropagation has also been tested on olive to produce highquality plantlets, especially of varieties that are interesting from a commercial point of view, but have a low rooting potential (Mangal et al., 2014; Micheli et al., 2010). Although several improvements have been achieved in the last years, the in vitro culture of olive is currently not a technique used in commercial laboratories. Such failure is mainly due to the different behavior of the various cultivars, which requires setting up a specific protocol for each variety (Bahrami et al., 2010; Lambardi and Rugini, 2003; Rostami and Shahsavar, 2012), and the use of zeatin, which is very expensive (Mendozade Gyves et al., 2008). To solve or reduce these problems, efforts have been made to identify alternative cytokinins or compounds/ protocols able to improve the regeneration efficiency of the explants to reduce the unit cost of regenerated shoots (Ali et al., 2009; Mendoza-de Gyves et al., 2008).

Recently, the use of natural substances as components of the media able to improve explant regeneration is gaining interest. These substances are called "complex mixtures" and consist of coconut water, malt extract, potato extract, yeast extract, homogenized banana, orange juice, seaweed compound, and hydrolyzed casein (Baque et al., 2011; Boase et al., 1993; Einset, 1978; Molnár et al., 2011; Souza et al., 2013). They provide several compounds, such as amino acids, peptides, carbohydrates, vitamins, and growth regulators. However, the type and quantity of the supplemented substances for success of in vitro cultivation vary according to the species and variety (Molnár et al., 2011; Thorpe et al., 2008).

We propose including neem oil among the "complex mixtures." This oil, extracted from the seeds of Azadirachta indica (A. Juss.), has been known and used for a long time in agriculture, as a fertilizer, soil conditioner and, especially, as a pesticide (Lokanadhan et al., 2012). Triglycerides make up about $97.7 \%$ of the oil, with oleic, linoleic, stearic, and palmitic fatty acids being the main ones (Djibril et al., 2015). The unsaponifiable fraction contains sterols and tocopherols (with $\beta$-sitosterol and $\gamma$-tocopherol as the major sterol and tocopherol components, respectively) (Djibril et al., 2015). It also contains vitamin $E$, phenols, and many triterpenoids of which azadirachtin is the most well known and studied (Devi and Maji, 2011; Nahak and Sahu, 2011).

The aim of this study was to test the use of neem oil as a "complex mixture" added to the culture medium for the proliferation of the olive cultivar Moraiolo to improve its regeneration efficiency. To our knowledge, this is the first attempt at using neem oil for in vitro plant regeneration.

\section{Materials and Methods}

The initial explants were 1-cm long uninodal segments of shoots with two leaves and two axillary buds. They were excised from previously proliferated masses cultured in aseptic conditions in the OM (Rugini, 1984), with the addition of $4 \mathrm{mg} \cdot \mathrm{L}^{-1}$ of zeatin, $30 \mathrm{~g} \cdot \mathrm{L}^{-1}$ of sucrose, and $7 \mathrm{~g} \cdot \mathrm{L}^{-1}$ of agar, according to Mencuccini et al. (1997). These explants were placed on the same proliferation medium enriched with four concentrations of neem oil $\left(0\right.$ - control, $0.1,0.5$, and $\left.1.0 \mathrm{~mL} \cdot \mathrm{L}^{-1}\right)$ added before sterilization. 'Moraiolo' was chosen because it is a cultivar that is difficult to multiply by cutting and hence there is interest in propagating it by using in vitro culture Neem oil in the form of the commercial product 
Table 1. Effects of four concentrations of neem oil added to the medium on the proliferation of 'Moraiolo' uninodal explants evaluated after 45 d of subculture.

\begin{tabular}{|c|c|c|c|c|c|c|c|c|}
\hline $\begin{array}{l}\text { Neem oil } \\
\left(\mathrm{mL} \cdot \mathrm{L}^{-1}\right)\end{array}$ & $\begin{array}{c}\text { Explant survival } \\
(\%)\end{array}$ & $\begin{array}{l}\text { Shoots } \\
\text { (n) }\end{array}$ & $\begin{array}{l}\text { Shoot length } \\
(\mathrm{mm})\end{array}$ & $\begin{array}{l}\text { Internode length } \\
(\mathrm{mm})\end{array}$ & $\begin{array}{l}\text { Multiplication } \\
\text { rate }(n)\end{array}$ & $\begin{array}{l}\text { Leaves } \\
\quad(n)\end{array}$ & $\begin{array}{c}\text { Fresh wt } \\
\text { (mg/explant) }\end{array}$ & $\begin{array}{c}\text { Dry wt } \\
\text { (mg/explant) }\end{array}$ \\
\hline 0.0 & $96.7 \mathrm{a}$ & $1.8 \mathrm{a}$ & $26.0 \mathrm{~b}$ & $6.2 \mathrm{c}$ & $7.5 \mathrm{a}$ & $19.6 \mathrm{a}$ & $377.4 \mathrm{c}$ & $51.5 \mathrm{c}$ \\
\hline 0.1 & $96.7 \mathrm{a}$ & $1.7 \mathrm{a}$ & $41.9 \mathrm{a}$ & $10.6 \mathrm{a}$ & $7.4 \mathrm{a}$ & $20.9 \mathrm{a}$ & $710.2 \mathrm{a}$ & $95.4 \mathrm{a}$ \\
\hline 0.5 & $60.0 \mathrm{~b}$ & $1.3 \mathrm{~b}$ & $24.6 \mathrm{~b}$ & $8.4 \mathrm{~b}$ & $4.0 \mathrm{~b}$ & $11.5 \mathrm{~b}$ & $557.3 \mathrm{~b}$ & $62.7 \mathrm{~b}$ \\
\hline 1.0 & $0.0 \mathrm{c}$ & - & - & - & - & - & - & - \\
\hline
\end{tabular}

All data were submitted to analysis of variance and means were separated with the Tukey's test, using the SISVAR statistical program. In each column, means followed by different letters are significantly different for $P \leq 0.05$.

Neem Italia ${ }^{\circledR}$ (Argan Italia, Moniga del Garda, Italy) without any previous treatment was used. After the addition of all compounds, the $\mathrm{pH}$ of all media was adjusted to 5.6. They were poured into glass vessels $(100 \mathrm{~mL} / \mathrm{vessel})$, which were then autoclaved at $115{ }^{\circ} \mathrm{C}$ for $20 \mathrm{~min}$. Successively, under aseptic conditions, the uninodal explants were placed in the glass vessels (10 explants/vessel) which were sealed with tape. The four treatments were arranged in a completely randomized design with three replications (one vessel each) per treatment. The cultures were maintained for $45 \mathrm{~d}$ in a growth chamber at $22 \pm 2{ }^{\circ} \mathrm{C}$ under a $16-\mathrm{h}$ light photoperiod, with cool white fluorescent tubes producing a photon flux density of $40 \mu \mathrm{E} \cdot \mathrm{m}^{-2} \cdot \mathrm{s}^{-1}$. At the end of the subculture, explant survival, number and length of shoots, multiplication rate (number of usable nodes obtained from each explant), number of leaves, and fresh and dry proliferated weights were recorded. In addition, the average internode length of the proliferated shoots was calculated (considering only the length and nodes of the main shoots). Then, the concentration of neem oil, which gave the best result, was compared with the control for two other subsequent subcultures to evaluate the consistency/reliability of the results.

All data were submitted to analysis of variance (ANOVA), according to a completely randomized design or a factorial design. Means were separated with the Tukey's test, using the SISVAR statistical program (Ferreira, 2011).

\section{Results and Discussion}

The addition of different concentrations of neem oil to the OM showed that, after $45 \mathrm{~d}$ of culture, the best results were obtained with $0.1 \mathrm{~mL} \cdot \mathrm{L}^{-1}$ (Table 1 ). Indeed, there was an increase in shoot length and, especially, in proliferated fresh and dry weights with respect to both the control $\left(0 \mathrm{~mL} \cdot \mathrm{L}^{-1}\right.$ of neem oil $)$ and the higher concentrations of neem oil. For the other parameters (Table 1), there were no statistically significant differences between the control treatment and that with $0.1 \mathrm{~mL} \cdot \mathrm{L}^{-1}$ of neem oil. The concentrations of 0.5 and 1.0 $\mathrm{mL} \cdot \mathrm{L}^{-1}$ caused $40 \%$ and $100 \%$ mortality of the explants, respectively. This is probably because of a phytotoxic effect of these amounts of neem oil to the explants. In this regard, it can be considered that the hydrophobic character of the oil can cause a reduction in water absorption and, consequently, of solubilized minerals from the medium (Cyr, 2014).

The comparison of the best concentration of neem oil $\left(0.1 \mathrm{~mL} \cdot \mathrm{L}^{-1}\right)$ with the control (no neem oil added) for three consecutive subcultures was carried out applying a factorial design for the analysis of data, using as factors the concentration of neem oil $\left(0 \mathrm{~mL} \cdot \mathrm{L}^{-1}\right.$ - control, and $0.1 \mathrm{~mL} \cdot \mathrm{L}^{-1}$ ) and the three subcultures. The ANOVA showed no interaction effect with the exception of the multiplication rate and the total number of leaves on the proliferated shoots for which there was an interaction effect between the concentration of neem oil and the subculture. Therefore, the results are shown as interaction for the multiplication rate and the total number of leaves (Table 2) and as main effects of the two factors considered for the other parameters (Tables 3 and 4).

The use of $0.1 \mathrm{~mL} \cdot \mathrm{L}^{-1}$, with respect to the control, showed no differences in the percentage of explant survival and shoot number produced by each explant, whereas it gave higher values of shoot length $(+74 \%)$ and proliferated fresh $(+112 \%)$ and dry $(+88 \%)$ weights (Table 3; Fig. $1 \mathrm{~A}$ and $\mathrm{B}$ ). It is important to note that the shoot length refers only to the main proliferated shoots without considering possible secondary/adventitious sprouts. Regarding the multiplication rate and the total number of leaves on the proliferated shoots, the use of $0.1 \mathrm{~mL} \cdot \mathrm{L}^{-1}$ with respect to the control showed similar values in the first subculture and higher values in the second $(+55 \%$ and $+42 \%$, respectively) and third $(+32 \%$ and $+39 \%$, respectively) subcultures (Table 2), indicating a clear interaction effect (the effect of neem oil depended on the combination with the subculture). For the other parameters there were no effects of the subculture (Table 4). Olive has a strong apical dominance which causes a low formation of secondary axillary shoots (Mendoza-de Gyves et al., 2008). Thus, uninodal explants with two opposed lateral buds usually develop just one shoot or, occasionally, two. Consequently, multiplication rate in olive is mainly determined by the number of nodes on the proliferated shoots produced in each subculture by the initial explant (Lambardi et al., 2013; Leva et al., 2013). However, adventitious secondary sprouts can develop from the proliferated shoots and they can contribute to increasing the total number of nodes from each explant. This was the case of shoots proliferated in the medium with the addition of neem oil. Indeed, about $20 \%$ of the nodes were derived from the development of secondary adventitious sprouts (Fig. 1C). The production of nodes from the development of secondary adventitious sprouts was also obtained by Mendoza-de Gyves et al. (2008), in three different olive cultivars, through the addition of dikegulac to the proliferation medium. The
Table 2. Effects of the interaction between the concentration of neem oil and the subculture on the multiplication rate and total number of leaves on the proliferated shoots.

\begin{tabular}{lccc}
\hline $\begin{array}{l}\text { Neem oil } \\
\left(\mathrm{mL} \cdot \mathrm{L}^{-1}\right)\end{array}$ & $\begin{array}{c}\text { Subculture } \\
(n)\end{array}$ & $\begin{array}{c}\text { Multiplication } \\
\text { rate }(n)\end{array}$ & $\begin{array}{c}\text { Leaves } \\
(n)\end{array}$ \\
\hline 0.0 & 1 & $7.5 \mathrm{~b}$ & $19.6 \mathrm{~b}$ \\
& 2 & $5.2 \mathrm{c}$ & $14.4 \mathrm{c}$ \\
& 3 & $8.1 \mathrm{~b}$ & $22.0 \mathrm{~b}$ \\
0.1 & 1 & $7.4 \mathrm{~b}$ & $20.9 \mathrm{~b}$ \\
& 2 & $8.0 \mathrm{~b}$ & $20.4 \mathrm{~b}$ \\
& 3 & $10.7 \mathrm{a}$ & $30.6 \mathrm{a}$ \\
\hline
\end{tabular}

All data were submitted to analysis of variance and means were separated with the Tukey's test, using the SISVAR statistical program. In each column, means followed by different letters are significantly different for $P \leq 0.05$.

interaction between the use of $0.1 \mathrm{mg} \cdot \mathrm{L}^{-1}$ of neem oil and the subcultures indicates that neem oil was able to increase the multiplication rate, after an initial phase during which it had no effect on the number of nodes (Table 2). This can be explained considering that in some cases, as observed in Elingera elatior (Jack) R.M., an adaptation period to the new medium is necessary before it can produce the entire effect (Santos et al., 2016). The similar effect observed on the total number of leaves on the proliferated shoots can be easily explained considering that the number of nodes (multiplication rate) and the number of leaves are related because each node has two to three leaves and so the total number of leaves is related to the number of nodes.

Overall, the results show that an appropriate amount of neem oil can significantly improve the regeneration of olive by mainly improving the vigor of the proliferated shoots, which were much longer, and by reducing apical dominance with the consequent development of secondary adventitious shoots. Therefore, the higher fresh and dry weights of the proliferated shoots were the result of longer internodes/shoots and the development of secondary adventitious sprouts with the production of a larger number of useable nodes (multiplication rate) (Tables 2 and 3). Improvements in the growth of the explants of 'Moraiolo' or other olive cultivars have also been obtained by adding BAP or dikegulac to the medium containing zeatin (Ali et al., 2009; Mendoza-de Gyves et al., 2008 ) or coconut water in combination with BAP without zeatin (Peixe et al., 2007). These results together with ours indicate that there is potential for greater growth of proliferated explants of olive and that neem oil is a natural compound that could significantly exploit this potential. The increase in 
Table 3. Main effects of two concentrations of neem oil added to the medium on the proliferation of 'Moraiolo' uninodal explants in three subsequent subcultures. Each value represents the mean of three subsequent subcultures.

\begin{tabular}{lcccccc}
\hline $\begin{array}{l}\text { Neem oil } \\
\left(\mathrm{mL} \cdot \mathrm{L}^{-1}\right)\end{array}$ & $\begin{array}{c}\text { Explant survival } \\
(\%)\end{array}$ & $\begin{array}{c}\text { Shoots } \\
(\mathrm{n})\end{array}$ & $\begin{array}{c}\text { Shoot length } \\
(\mathrm{mm})\end{array}$ & $\begin{array}{c}\text { Internode length } \\
(\mathrm{mm})\end{array}$ & $\begin{array}{c}\text { Fresh wt } \\
(\mathrm{mg} / \mathrm{explant})\end{array}$ & $\begin{array}{c}\text { Dry wt } \\
(\mathrm{mg} / \mathrm{explant})\end{array}$ \\
\hline 0.0 & $98.9 \mathrm{a}$ & $1.7 \mathrm{a}$ & $24.9 \mathrm{~b}$ & $6.1 \mathrm{~b}$ & $338.9 \mathrm{~b}$ & $49.8 \mathrm{~b}$ \\
0.1 & $96.7 \mathrm{a}$ & $1.6 \mathrm{a}$ & $43.4 \mathrm{a}$ & $10.1 \mathrm{a}$ & $720.4 \mathrm{a}$ & $93.4 \mathrm{a}$ \\
\hline
\end{tabular}

All data were submitted to analysis of variance and means were separated with the Tukey's test, using the SISVAR statistical program. In each column, means followed by different letters are significantly different for $P \leq 0.05$.

Table 4. Main effects of three subcultures on the proliferation of 'Moraiolo' uninodal explants obtained with two different concentrations of neem oil in the medium $\left(0.0\right.$ and $\left.0.1 \mathrm{~mL} \cdot \mathrm{L}^{-1}\right)$ in three subsequent subcultures. Each value represents the mean of the two concentrations of neem oil used in all the subcultures.

\begin{tabular}{lccccc}
\hline $\begin{array}{l}\text { Subculture } \\
(n)\end{array}$ & $\begin{array}{c}\text { Explant survival } \\
(\%)\end{array}$ & $\begin{array}{c}\text { Shoots } \\
(n)\end{array}$ & $\begin{array}{c}\text { Shoot length } \\
(\mathrm{mm})\end{array}$ & $\begin{array}{c}\text { Fresh wt } \\
(\mathrm{mg} / \mathrm{explant})\end{array}$ & $\begin{array}{c}\text { Dry wt } \\
(\mathrm{mg} / \mathrm{explant})\end{array}$ \\
\hline 1 & $96.7 \mathrm{a}$ & $1.8 \mathrm{a}$ & $33.9 \mathrm{a}$ & $543.8 \mathrm{a}$ & $73.5 \mathrm{a}$ \\
2 & $100.0 \mathrm{a}$ & $1.5 \mathrm{a}$ & $32.7 \mathrm{a}$ & $476.8 \mathrm{a}$ & $64.4 \mathrm{a}$ \\
3 & $100.0 \mathrm{a}$ & $1.8 \mathrm{a}$ & $37.2 \mathrm{a}$ & $568.4 \mathrm{a}$ & $76.9 \mathrm{a}$ \\
\hline
\end{tabular}

All data were submitted to analysis of variance and means were separated with the Tukey's test, using the SISVAR statistical program. In each column, means followed by different letters are significantly different for $P \leq 0.05$.

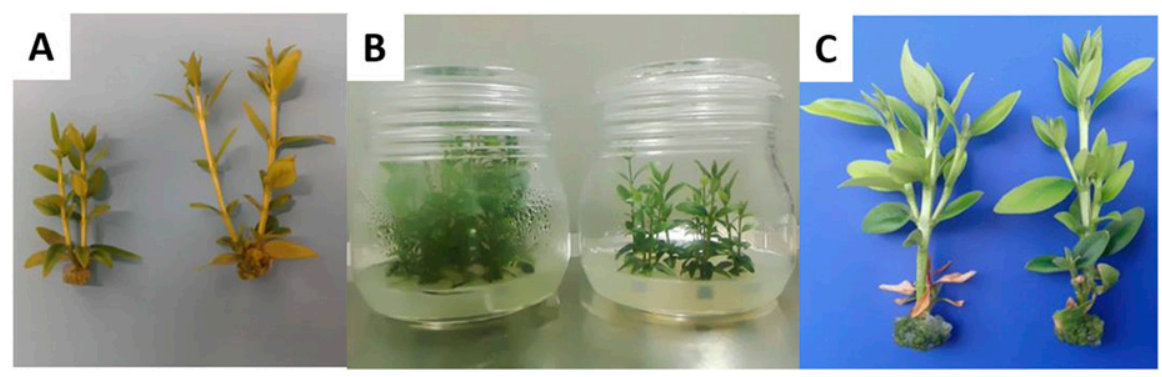

Fig. 1. Comparison between the vegetative behavior of explants grown on Olive Medium (OM) without neem oil (left) and with $0.1 \mathrm{~mL} \cdot \mathrm{L}^{-1}$ neem oil (right) (A). Vessel containing the explants grown with the addition of $0.1 \mathrm{~mL} \cdot \mathrm{L}^{-1}$ neem oil (left) and without neem oil (right) (B). Details of proliferated shoots obtained with the addition of $0.1 \mathrm{~mL} \cdot \mathrm{L}^{-1}$ of neem oil in which the growth of secondary adventitious sprouts is visible $(\mathbf{C})$.

internode/shoot length of the proliferated shoots is particularly important because it has been reported that longer uninodal explants can be subcultured better (Sghir et al., 2005). Moreover, obtaining more robust explants is also important at the time of transplanting to ex vitro conditions, because vigorous plants are more capable of adapting to the external environment (Demo et al., 2008).

Neem oil contains several compounds that are not easy to relate to a higher growth (Devi and Maji, 2011; Djibril et al., 2015; Kraus, 1995). However, it seems apparent that the effects are not because of the addition of nutritional compounds because the amount of oil added to the medium was very low $\left(0.1 \mathrm{~mL} \cdot \mathrm{L}^{-1}\right)$ compared with the significant increase in the proliferated dry weight that occurred. Neem oil seems to act as a growth promoter with effects that resemble those of some growth regulators, such as gibberellins and cytokinins (longer internodes and development of secondary adventitious sprouts). However, no data about the presence of these substances in neem oil are available, although these compounds are present in seeds. Therefore, to further understand the mechanism

\section{Literature Cited}

Ali, A., T. Ahmad, N.A. Abbasi, and I.A. Hafiz. 2009. Effect of different media and growth regulators on in vitro shoot proliferation of olive cultivar 'Moraiolo'. Pak. J. Bot. 41:783795.

Bahrami, M.K., A. Motallebi Azar, and M.R. Dadpour. 2010. Influence of thidiazuron in direct shoot regeneration from segments of in vitro leaves, and axillary and apical buds of Olive (Olea europaea). Acta Hort. 884:383389.

Balla, I. and L. Mansvelt. 2013. Micropropagation of peach rootstocks and cultivars. Methods Mol. Biol. 11013:137-148.

Baque, M.A., Y.K. Shin, T. Elshmari, E.J. Lee, and K.Y. Paek. 2011. Effect of light quality, sucrose and coconut water concentration on the microporpagation of Calanthe hybrids ('Bukduseong' $x$ 'Hyesung' and 'Chunkwang' $x$ 'Hyesung'). Austral. J. Crop Sci. 5(10):12471254

Boase, M.R., S. Wright, and P.L. McLeay. 1993. Coconut milk enhancement of axillary shoot growth in vitro of kiwifruit. N. Z. J. Crop Hort. Sci. 21:171-176.

Cyr, K. 2014. Effects of foliar and soil applications of cold-pressed neem oil solutions on vigor and leaf phytotoxicity in cucurbits. Univ. Wisconsin Colleges Student Res. J. 1:1-18.

Demo, P., P. Kuria, A.B. Nyende, and E.M Kahangi. 2008. Table sugar as an alternative low cost medium component for in vitro micropropagation of potato. Afr. J. Biotechnol. 7:2578-2584.

Devi, N. and T.K. Maji. 2011. Neem seed oil: Encapsulation and controlled release-Search for a greener alternative for pest control. In: M. Stoytcheva (ed.). Pesticides in the modern world-Pesticides use and management InTech. <https://www.intechopen.com/books/ pesticides-in-the-modern-world-pesticides-useand-management $>$.

Djibril, D., F. Mamadou, V. Gérard, M.C. Geuye, S. Oumar, and R. Luc. 2015. Physical characteristics, chemical composition and distribution of constituents of the neem seeds (Azadirachta indica A. Juss) collected in Senegal. Res. J. Chem. Sci. 5:52-58.

through which neem oil produces its effects, studies are needed to better characterize its composition and to evaluate its effects also in other conditions/species.

\section{Conclusions}

The addition of neem oil at a low concentration $\left(0.1 \mathrm{mg} \cdot \mathrm{L}^{-1}\right)$ to the nutritive medium was able to improve significantly the micropropagation of olive explants, causing the production of longer shoots, increase in the multiplication rate and, as an overall result, increase in the total fresh and dry proliferated weights. To our knowledge, this is the first report of a significant and beneficial effect of the use of neem oil on in vitro plant regeneration. Therefore, neem oil can be considered a new "complex mixture" able to improve in vitro shoot proliferation that can be added to the others reported in the literature (Molnár et al., 2011; Souza et al., 2013). The use of neem oil as a "complex mixture" is very interesting because shoot proliferation is improved by using a natural compound, which is also economical. Other studies are in progress to further optimize the use of neem oil in olive and to evaluate its effects on other species.
Dobránszki, J. and J.A. Silva. 2010. Micropropagation of apple-A review. Biotechnol. Adv. 28:462-488.

Einset, J.W. 1978. Citrus tissue cultureStimulation of fruit explant cultures with orange juice. Plant Physiol. 62:885-888.

Ferreira, D.F. 2011. Sisvar: a computer statistical analysis system. Ciencia e Agrotecnologia (UFLA) 35(6):1039-1042.

Jain, S.M. and H. Haggman. 2007. Preface. In: S.M. Jain and H. Haggman (eds.). Protocols for micropropagation of woody trees and fruits. Springer, Dordrecht, The Netherlands.

Kavand, S., M.J. Kermani, A. Haghnazari, P. Khosravi, and M.R. Azimi. 2011. Micropropagation and medium-term conservation of Rosa pulverulenta. Acta Sci. Agron. 33:297-301.

Kraus, W. 1995. Biologically active ingredientsazadirachtin and other triterpenoids. In: $\mathrm{H}$. Schutterer (ed.). The neem tree Azadirachta indica A. Juss and other meliaceous plants. Weinheim, New York, NY.

Lambardi, M., E.A. Ozudogru, and R. Roncasaglia. 2013. In vitro propagation of olive (Olea europaea L.) by nodal segmentation of elongated shoots. In: M. Lambardi, E.A. Ozudogru, and S.M. Jain (eds.). Protocols for micropropagation of selected economically-important horticultural plants. Springer, New York, NY. 
Lambardi, M. and E. Rugini. 2003. Micropropagation of olive (Olea europaea L.). In: S.M. Jain and K. Ishii (eds.). Micropropagation of woody trees and fruits. Kluwer Academic Publishers, Dordrecht, The Netherlands.

Leva, A., H. Sadeghi, and R. Petruccelli. 2013. Carbohydrates modulate the in vitro growth of olive microshoots I. The analysis of shoot growth and branching patterns. J. Plant Growth Regulat. 32:53-60.

Lokanadhan, S., P. Muthukrishnan, and S. Jeyaraman. 2012. Neem products and their agricultural applications. J. Biopesticides 5:72-76.

Mangal, M., D. Sharma, M. Sharma, and S. Kumar. 2014. In vitro regeneration in olive (Olea europaea L.), cv 'Frontio' from nodal segments. Indian J. Expt. Biol. 52:912-916.

Mencuccini, M., M. Micheli, and A. Standardi. 1997. Micropropagazione dell'olivo: Effetto di alcune citochinine sulla proliferazione. Italus Hortus 4:32-37.

Mendoza-de Gyves, E., F.R. Mira, F. Ruiu, and E. Rugini. 2008. Stimulation of node and lateral shoot formation in micropropagation of olive (Olea europaea L.) by using dikegulac. Plant Cell Tissue Organ Cult. 92:233-238.
Micheli, M., A.W. El Behi, D. Zakhour, M. Yasin, and A. Standardi. 2010. In vitro proliferation of olive ('Dolce Agogia' and 'Moraiolo'): Effect of different cytokinins. Acta Hort. 884:587590.

Molnár, Z., E. Virág, and V. Ördög. 2011. Natural substances in tissue culture media of higher plants. Acta Biol. Szeged. 55:123-127.

Nahak, G. and R.K. Sahu. 2011. Evaluation of antioxidant activity of flower and seed oil of Azadirachta indica A. Juss. J. Appl. Natl. Sci. 3 (1):78-81.

Peixe, A., A. Raposo, R. Lourenco, H. Cardoso, and A. Macedo. 2007. Coconut water and BAP successfully replaced zeatin in olive (Olea europaea L.) micropropagation. Scientia Hort. 113:1-7.

Rkhis, A.C., M. Maalej, N. Drira, and A. Standardi. 2011. Micropropagation of olive tree Olea europaea L. 'Oueslati'. Turk. J. Agr. For. 35:403-412.

Rostami, A.A. and A.R. Shahsavar. 2012. In vitro micropropagation of olive (Olea europaea L.) 'Mission' by nodal segments. J. Biol. Environ. Sci. 6:155-159.

Rugini, E. 1984. In vitro propagation of some olive (Olea europaea sativa L.) cultivars with different root-ability, and medium development using analytical data from developing shoots and embryos. Scientia Hort. 24:123134.

Santos, E.O., A.A.J. Rodrigues, E.R. Silva, and A.C.P.P. Carvalho. 2016. Multiplicação de bastão-do-imperador em resposta a concentrações de BAP e número de subcultivos. Ornam. Hort. 22:88-93.

Sghir, S., F. Chatelet, N. Ouazzani, F. Dosba, and I. Belkoura. 2005. Micropropagation of eight Moraccan and French olive cultivars. HortScience 40:193-196.

Souza, R.A.V., F.T. Braga, T.A. Setotaw, N.J. Vieira, P.H. Azevedo, V.H. Azevedo, and G.M.A. Cançado. 2013. Effect of coconut water on growth of olive embryos cultured in vitro. Cienc. Rural 43:290-296.

Thorpe, T.A., C. Stasolla, E.C. Yeung, G.J. De Klerk, A. Roberts, and E.F. George. 2008. The components of plant tissue culture media II: Organic additions, osmotic and $\mathrm{pH}$ effects, and support systems. In: E.F. George, M.A. Hall, and G-J. De Klerk (eds.). Plant propagation by tissue culture. Springer-Verlag, Dordrecht, The Netherlands. 